\title{
Geophysical characterization of the León-Chinandega aquifer, Nicaragua
}

\author{
Marvin Corriols • Torleif Dahlin
}

\begin{abstract}
Electrical geophysical surveys in the mode of vertical electrical soundings (VES) and continuous vertical electrical soundings (CVES) were conducted in the León-Chinandega plains, northwestern Nicaragua, in order to obtain detailed information about the geometry of the different hydrogeological layers in the aquifer and depth to the basement. A total of 51 VES were carried out within the plains. The results show a complex structure towards the north east of the area, and the southwestern part of the plains presents a smoother stratification. The geoelectrical measurements and borehole information indicate that the basement topography is characterized by hills and deep valleys with highly variable basement depths. Fifty CVES where done in a smaller area in the center of the plain. The resistivity data yielded considerable information revealing the existence of two main geoelectrical units. The combined interpretation of geological and geophysical data shows an environment typical of sedimentary volcanic coastal plains. The information collected during this investigation provides valuable data for estimating the fresh-water resources of the LeónChinandega aquifer system and for development of a groundwater management plan.
\end{abstract}

Résumé Des études géophysiques électriques de types sondages electriques verticaux (VES) et sondages elec-

Received: 6 March 2006 / Accepted: 4 December 2007

Published online: 25 January 2008

(C) Springer-Verlag 2007

M. Corriols (

Centro de Investigaciones Geocientíficas,

Universidad Nacional Autónoma de Nicaragua

(CIGEO, UNAN-Managua),

Col Miguel Bonilla No. 165,

P.O. Box A-131, Managua, Nicaragua

e-mail: marvin.corriols@tg.lth.se

Tel.: +505-277-0621

Fax: +505-277-0613

M. Corriols $\cdot$ T. Dahlin

Engineering Geology,

Lund University,

John Ericssons Väg 1,

P.O. Box 118, 22100, Lund, Sweden triques verticaux continus (CVES) ont été réalisées dans les plaines de León-Chinandega, dans le Nord-Ouest du Nicaragua, de manière à obtenir des informations détaillées sur la géométrie des différentes couches hydrogéologiques de l'aquifère ainsi que la profondeur du socle. Un total de 51 VES a été réalisé dans les plaines. Les résultats montrent une structure complexe vers le Nord-Est de la zone, tandis que la partie Sud-Ouest des plaines présente une stratification plus douce. Les mesures géo-électriques et les informations des forages indiquent que la topographie du socle est caractérisée par des collines et des vallées profondes avec des élévations du socle très variables. Cinquante CVES ont été réalisés dans une zone plus petite au centre de la plaine. Les données de résistivité ont apporté des informations considérables révélant l'existence de deux unités géo-électriques principales. L'interprétation combinée des données géologiques et géophysiques caractérise un environnement typique de plaines côtières sédimentaires volcaniques. L'information collectée lors de cette étude apporte des données qui peuvent servir à l'estimation des ressources en eau douce du système aquifère de León-Chinandega et à l'élaboration d'un plan de gestion des eaux souterraines.

Resumen Estudios geoelectricos en la modalidad de sondeos eléctricos verticales (SEV) y sondeos eléctricos verticales continuos (SEVC) fueron realizados en la planicie de León-Chinandega, nor-oeste de Nicaragua, para obtener información detallada de la geometría de las diferentes capas hidrogeológicas en el acuífero y la profundidad al basamento. Un total de 51 SEV fueron realizados en la planicie. Los resultados muestran una estructura compleja hacia el nor-este del área, la parte suroeste de la planicie presenta una estratificación más simple. Las mediciones geoeléctricas y la información de pozos indican que la topografía del basamento está caracterizada por colinas y valles profundos con grandes variaciones en las profundidades del basamento. Cincuenta SEVC fueron realizados en un área más pequeña en el centro de la planicie. Los datos de resistividad brindaron considerable información revelando la existencia de dos unidades geoeléctricas principales. La interpretación combinada de los datos geológicos y geofísicos muestra un ambiente típico de las planicies volcanosedimentarias costeras. La información obtenida durante esta investigación provee información valiosa para la 
estimación de los recursos de agua potable del sistema acuífero de León-Chinandega y para el desarrollo de un plan de manejo de las aguas subterráneas.

Keywords Geophysical methods - Vertical electrical soundings $\cdot$ Aquifer geometry $\cdot$ Coastal aquifers . Nicaragua

\section{Introduction}

The León-Chinandega plains are located in the north western part of Nicaragua. The area is limited to the southwest by the coast of the Pacific Ocean, and to the northeast by the Nicaraguan volcanic chain. The rivers El Realejo and Chiquito are located near its northwestern and southeastern limits, respectively (Fig. 1a). The topography to 100 masl at its northeastern limit, whereas the Nicaraguan volcanic chain reaches altitudes of 1,745 masl at San Cristobal volcano (Fig. 1b). is flat with altitudes ranging from sea level at the coastline

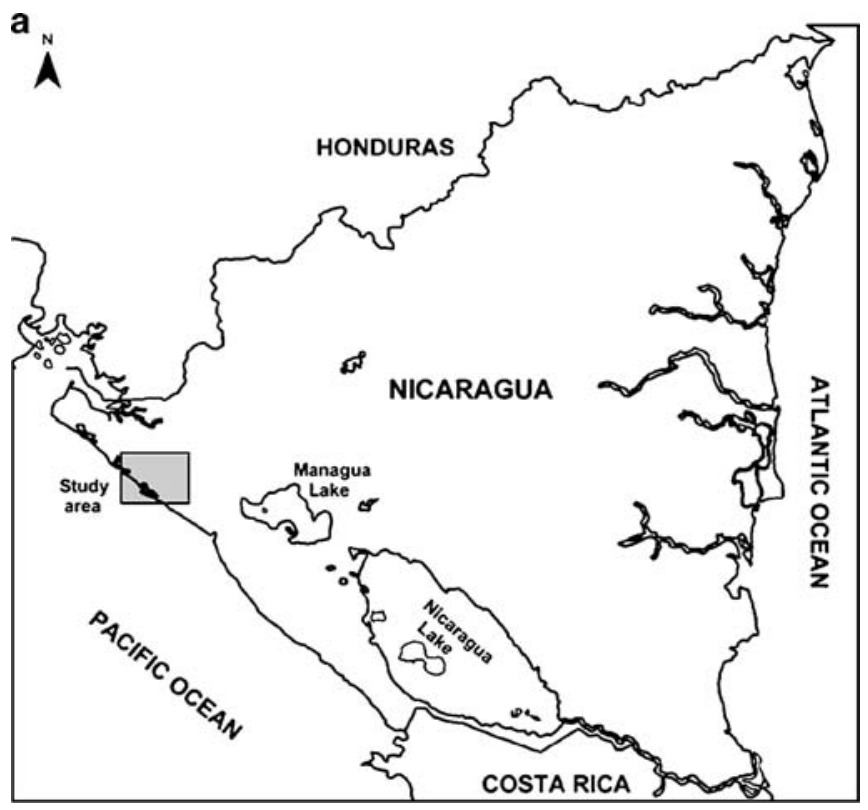

b

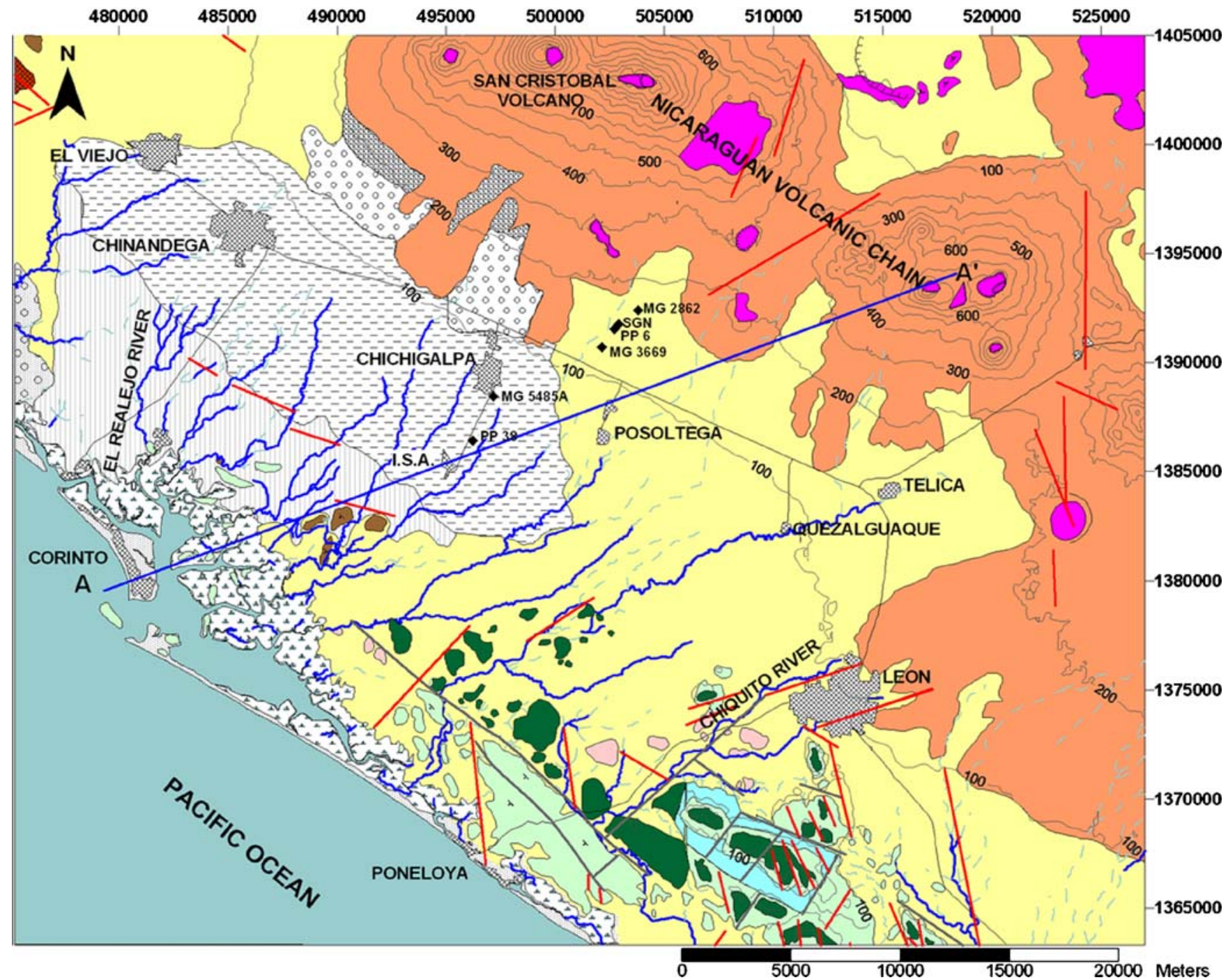




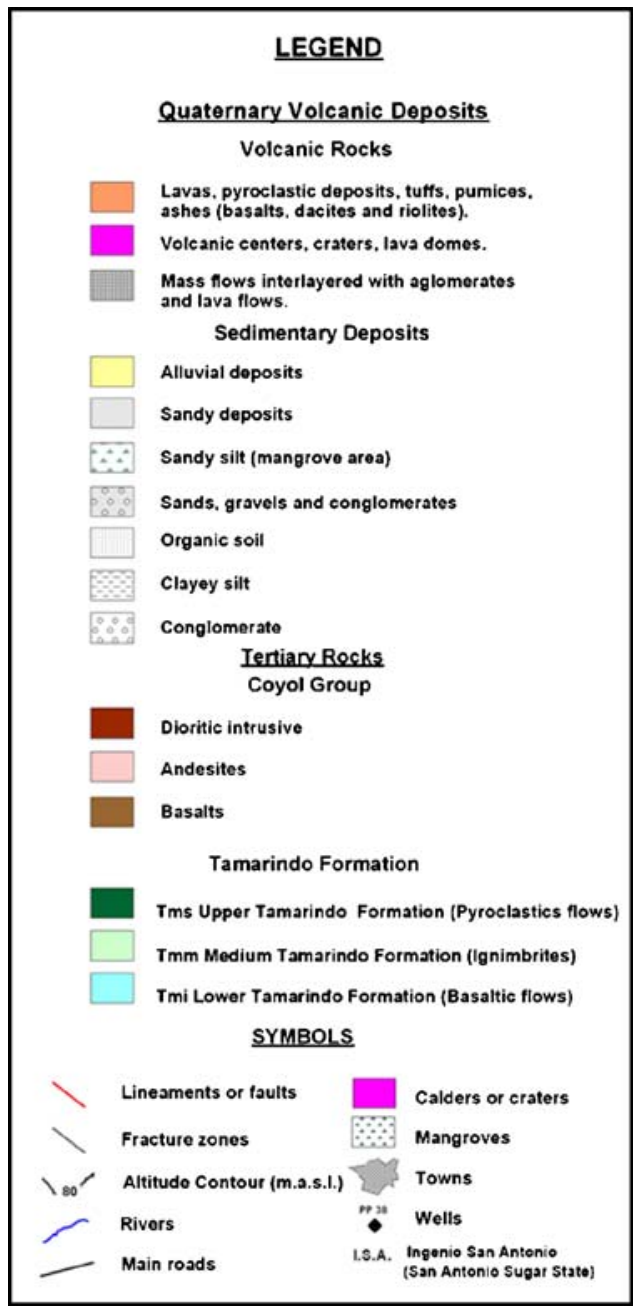

For more than 40 years, the León-Chinandega area was the major producer of cotton in the country and large quantities of pesticides and fertilizers were used without any control or regulation, resulting in one of the most serious environmental problems in Nicaragua. The irrational use of pesticides has caused diffuse contamination of the area. Some of these pollutants are highly resistant to degradation and tend to stay adsorbed to the soil and or stable in groundwater for years, severely polluting the aquifer. The aquifer of León-Chinandega represents one of the largest groundwater reservoirs of Nicaragua and it is intensively used today for irrigation and human consumption.

At the present time, the cultivation of cotton has diminished almost completely and with it the use of associated pesticides. The agricultural activity in the region is still important for the economy of the country, but it involves a wider spectrum of crops, sugar cane being the most important. Unfortunately, despite the daily use of local groundwater for both drinking and irrigation, little is known about the actual state of pollution in the aquifer.

In recent years, different studies have focused on the environmental situation of the León-Chinandega area. Most of the studies show that residues of pesticides can be found in groundwater, surface water, and soils (Alvarez 1994; Lopez et al. 2000; Väisänen et al. 2001; Delgado 2003).

Since 1999, the Autonomous National University of Nicaragua in cooperation with Lund University, Sweden and Aarhus University, Denmark has been developing a research project in the León-Chinandega area. The studies focus on the environmental and hydrogeological situation of the plains. Hydrochemical, isotope and pesticide analyses were carried out in order to obtain information

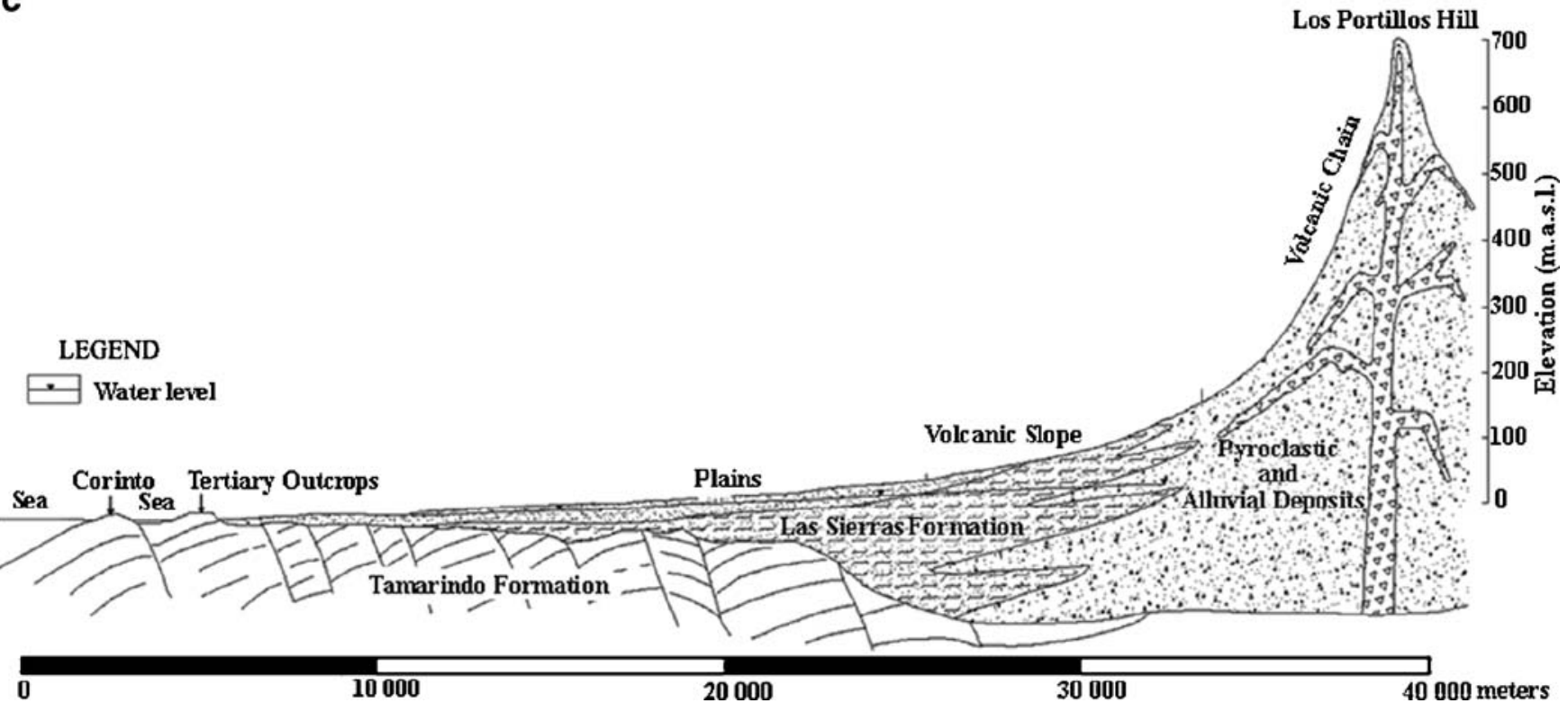

$\Delta$

Fig. 1 a Location of the study area. b Geological map of the León-Chinandega area (CIGEO 1999). c Geological cross section of the León-Chinandega plains (recreated from United Nations 1974) 
regarding the physical characteristics, composition, origin and contamination level of the groundwater in the area (Dahlberg and Odebjer 2002; Corriols 2003). Geophysical methods were used in order to provide needed information about geometry and variation in properties of the LeónChinandega aquifer (Corriols 2003; Ryom 2004; Cáceres 2005).

The direct current resistivity method was selected due to its capability to differentiate geological strata and to map subsurface geology. Vertical electrical soundings were used to obtain detailed information of the area, and continuous vertical electrical soundings were used for collecting information of the aquifer units in electrical cross sections. The work presented compiles the results obtained with the direct current resistivity method within this research program, which is used as a tool for refining the conceptual hydrogeological model.

\section{Geology and hydrogeology of the area}

The study area is dominated by four geomorphologic units, the León-Chinandega plains, the volcanic foothills, the Nicaraguan volcanic chain and the Tamarindo Plateaus. The first one is an extended volcanic plain between 0 and 100 masl; it starts in the slopes of the volcanic chain (volcanic foothills) and ends at the Pacific coast. The topographic gradient is very low, around $0.6 \%$.
In areas of discharge for the rivers and estuaries, the terrain becomes swampy, a product of the shallow water table and tidal processes. The volcanic foothills are located within 100-300 masl and present a gentle slope, around $3 \%$. The Nicaraguan volcanic chain is located at the northeastern boundary of the study area, and is a natural watershed divide. The volcanic structures can vary from semi-destroyed due to erosion and tectonic events, to well formed volcanic cones with a recent volcanic activity. The lava composition ranges between andesites, dacites, normal basalts and olivine basalts. The volcanoes present an increasingly steep topography with high altitude, the slopes range from 36 to $71 \%$. The Tamarindo Plateaus are hills comprised of Tertiary volcanic rocks; these hills present altitudes up to 300 masl The major outcrops are located west of the city of Leon and are sparsely disseminated along the coast (Fig. 1b).

The León-Chinandega aquifer system is comprised of three geological units: the alluvial and pyroclastic Quaternary deposits, which cover most of the surface of the area; Las Sierras Formation underlying the Quaternary deposits; and the Tamarindo Formation, which is the basement. Both upper units are considered as the main aquifer units (Fig. 1c).

The Tamarindo Formation has been studied by several authors such as Wilson (1942), McBirney and Williams (1965) and Kuang (1971). This formation has been defined as a sequence of volcanic ignimbrites and andesitic lavas

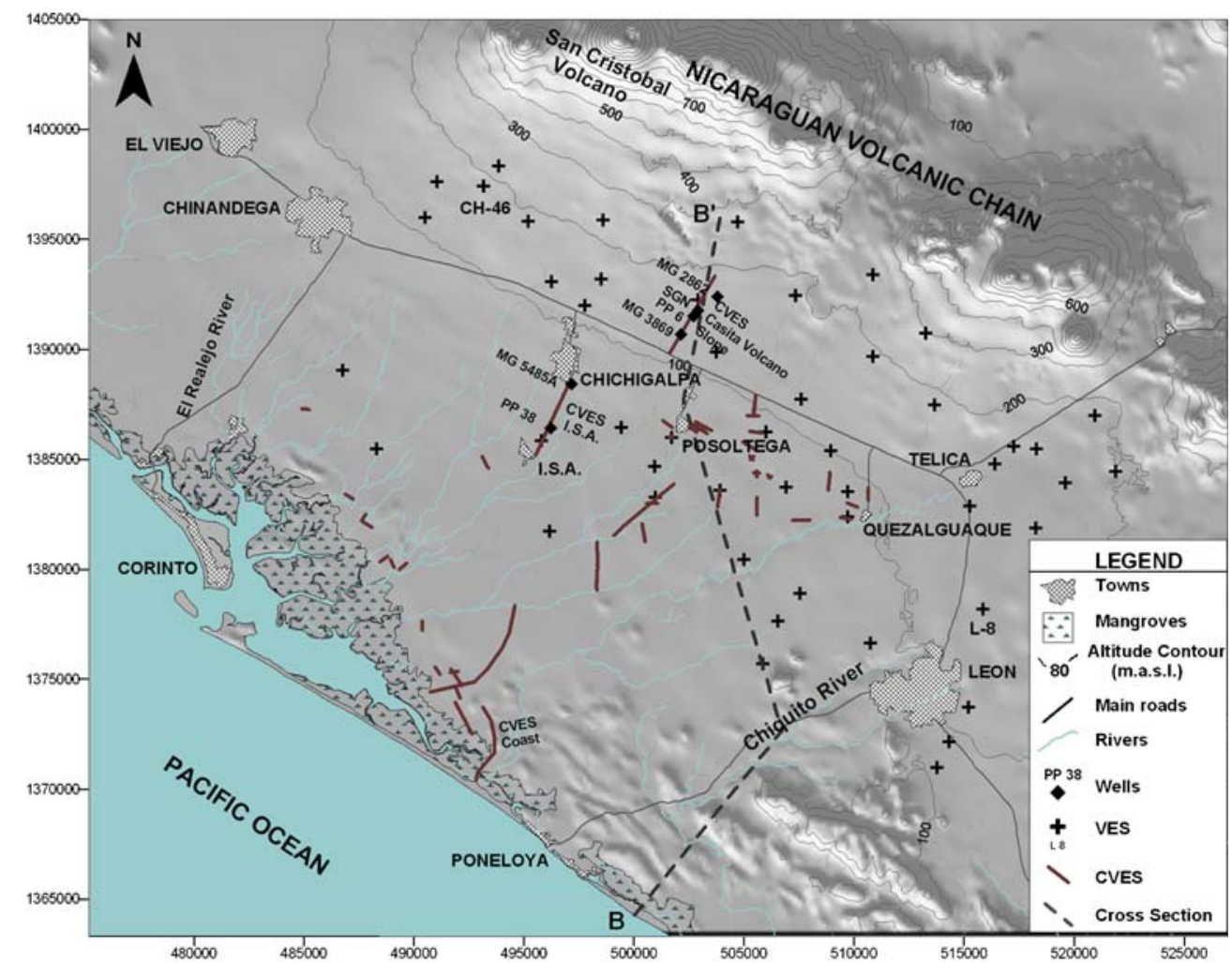

Fig. 2 Map of the León-Chinandega plains. The altitude contour interval is $100 \mathrm{~m}$ (above mean sea level). The geophysical soundings and electrical profiles carried out in the area (July and August 1999) are presented. The VES, CVES and geoelectrical cross section $B B$ ' are labeled 
by Wilson (1942), who named these sequences as the Tamarindo Formation based on the existence of extensive outcrops along the Tamarindo River.

The Tamarindo Formation extends in a fringe oriented NW-SE and parallel to the coastline, and has been subdivided in three members based on the lithological composition of the different volcanic sequences. The Miocene-Pliocene Tamarindo Formation has an age of 14.8 \pm 0.5 million years (Elming et al. 2001).

The Lower Tamarindo Formation is approximately $200 \mathrm{~m}$ thick and it is the only lava flow of andesiticbasaltic composition that is definitively older than the ignimbrites that belong to the Medium Tamarindo Formation. The ignimbrites are generally homogeneous and of rhyolitic composition. They have a porphyritic texture with some quartz and sandstone lenses. The coloration of these rocks is normally a rosy shade and they are generally present in outcrops that have been subjected to spheroidal weathering, giving rise to the formation of sandy floors produced by the disaggregation of the granular components. The thickness of the unit is approximately $175 \mathrm{~m}$. The Upper Tamarindo Formation is made up by several pyroclastic flows, with an approximate total thickness of $100 \mathrm{~m}$. Although large fragments are observed in the interior of the flows, the deposit is characterized by very high concentrations of quartz and plagioclase crystals. Occasionally the enrichment of quartz and plagioclases in the tuffs makes them resemble an acid intrusive rock. Inside the pyroclastic flows, fragments of basaltic and andesitic rocks are commonly found.

Las Sierras Group consists mainly of a diverse variety of pyroclastic materials such as tuffs (lithic and agglomeratic) and pumice (Kuang 1971). The tuffs are always intercalated with ashes, breccias and volcanic scoria; they have a regular compaction and are partially weathered. At the bottom of the Las Sierras Group, a clay layer formed by weathering processes is overlying the ignimbrites of the Tamarindo Formation.

The Pleistocene-Pliocene age for the Las Sierras Formation was determined by the lithological characteristics (Zoppis-Bracci and Del Guidicce 1958). The thickness of the formation is around $220 \mathrm{~m}$ (United Nations 1974).

The pyroclastics and alluvial deposits discordantly overly Las Sierras tuffs and in some coastal regions, the Tamarindo Formation. Silts, fine to coarse sands, ashes, lapilli, pumice and gravels constitute the deposits. During the sedimentation process, the coarser sediments have been deposited close to the volcanic chain and the fine ones close to the coast. The deposits are upper-Pleistocene to Recent in age (United Nations 1974).

The sedimentary deposits, which are products of the disintegration, transportation and deposition of volcanic materials, occupy large areas on the Leon-Chinandega plains. The Quaternary sediments range from sandy to silty-sandy materials, and packages of stratified conglomerates, sands and gravels. The thickness of the deposits ranges from a few $\mathrm{m}$ to $120 \mathrm{~m}$.
The Quaternary volcanic deposits include the derivative products of the volcanic chain. Those products have been deposited from the Pleistocene to Recent. The deposits consist of sequences of interstratified basaltic, andesitics and rhyolitic lavas and stratified pyroclastic materials that include pumice and tuffs with lapilli structures. The chemical composition of the magma in this region is basaltic with its subordinate dacitic and rhyolitic variants.

Within the plains three geological sub environments with different characteristics can be described. Near the coast, the geology is dominated by the presence of outcrops parallel to the coastline. The Tamarindo Formation is in some areas covered by coastal deposits, mainly sands and gravels, and by mangrove deposits, formed of silty and clayey sands (United Nations 1974). Zones of marine intrusion have been observed in areas where the Tamarindo Formation outcrops are absent (Fenzl 1983).

In the middle part of the plains, the geology is characterized by alluvial and volcanic deposits of great thickness. To the north of the plains, the geology becomes more complex towards the volcanic chain; lava flows from the different volcanic centers, and steep gullies, a product of the strong runoff, are common within the area.

The groundwater in the area originates mainly from direct infiltration of precipitation. The soils in the area have a high infiltration capacity, except for the soils close to the coast, which present impediments to the vertical flow of the water. The infiltration capacity of cultivated soils is four times greater than the infiltration capacity of noncultivated soils (United Nations 1974).

Because of the topographic conditions in the area and precipitation distribution, the highest infiltration rates are on the slopes of the volcanic chain (from May to October); in the central part of the plain the recharge is higher than in the lower areas. This is due to the smooth slope of the terrain and the presence of cultivated fields. Intensive irrigation can also be taken into account as a recharge source in some areas, even if it represents a small volume of the total recharge (United Nations 1974).

Three zones have been defined: (1) the upper recharge area, above 400 masl with a recharge value between 22 and $36 \%$ of the total; most of the soils in this zone correspond to coarse and gravelly sands; (2) the central recharge area, which lies within 400 to 10 masl (this has a recharge value of around 10 to $28 \%$ and consists of sandy soils); and (3) the discharge area, within 10 masl of the coastline, mostly covered by mangroves and formed by clayey soils (ARCAL 1999).

An isotopic study in the León-Chinandega area concludes that most of the groundwater from deep wells comes from altitudes over 200 masl In the excavated shallow wells, the local recharge process has taken 3 years or less. The water from the plains in the deep drilled wells (deeper than $40 \mathrm{~m}$ ) has an age greater than 10-13 years, and probably as much as 20 years (IAEA 1971).

Payne and Yurtsever (1973) carried out an isotopic investigation in order to determine the importance of direct recharge from rain in the Chinandega plain, 
specifically related to the precipitation on the slopes of the volcanic chain. Their results show that around $75-80 \%$ of the recharge of the deep aquifers in the area originates from recharge in the slopes above 280 masl (Payne and Yurtsever 1973).

Part of the water recharged in the upper recharge area is discharged in the vicinity of 80 masl and feeds the surface streams. To the south, due to the decrease of the bearing layer, caused by the presence of the shallow Tertiary rocks (Tamarindo Formation), the recharge is very low and almost all the groundwater is discharged into the ocean (United Nations 1974).

Two different flow systems are expected in the aquifer. The first one is a shallow flow system, mainly recharged from the central and low parts of the plain, discharging into springs, rivers and pumping wells (domestic and commercial). The second system is a deep regional flow system, recharged in the volcanic chain and discharged in the central and lower parts of the plain (Calderón 2003).

In 1999, a study in the region of Chinandega-León showed that the extraction of groundwater from dug and drilled wells was $237 \times 10^{4} \mathrm{~m}^{3} /$ year, and of this $234 \times 10^{4} \mathrm{~m}^{3} /$ year came from the drilled wells. The main use for the water from the drilled wells was for irrigation $(50 \%)$ and domestic use (11\%). In the case of dug wells, domestic use was the most important (92\%) and irrigation was small (2\%; INETER 2001).

A comparison of extracted water from 1970 and 1999 shows that the groundwater extraction in the plains has increased from $98 \times 10^{4}$ to $217 \times 10^{4} \mathrm{~m}^{3} /$ year. The number of wells increased also from 192 in 1970 to 549 in 1999 (INETER 2001).

Two geophysical methods used during the 1974 United Nations study were electrical and gravimetric. The main objective was to determine the thickness of the aquifer. The electrical method presented good results in the coastal areas where it was possible to differentiate the Tamarindo Formation from the aquifer, but towards the northeast, with the increase in thickness of the sediment filling, the soundings did not present differences on resistivity changes. The report concluded that this behavior could be caused by the low resistivity in the Tamarindo Formation or by the presence of a clay layer covering the basement which, due to its low resistivity, could block current penetration to larger depths.

The gravimetric results obtained show that it was impossible to establish the density contrasts between the Tamarindo Formation and the volcanic sediments due to the presence of a denser unit below the Tamarindo Formation. Assuming that one major change of density
Fig. 3 Vertical electrical soundings $\mathrm{CH}-46$ (volcanic slope area) and $L-8$ (plains area), located in the northern and southern part of the study area respectively (Corriols 2003). The locations for both VES are shown in Fig. 2. The VES located in the north of the area presented higher RMS (root mean square) values than the others located in the plains
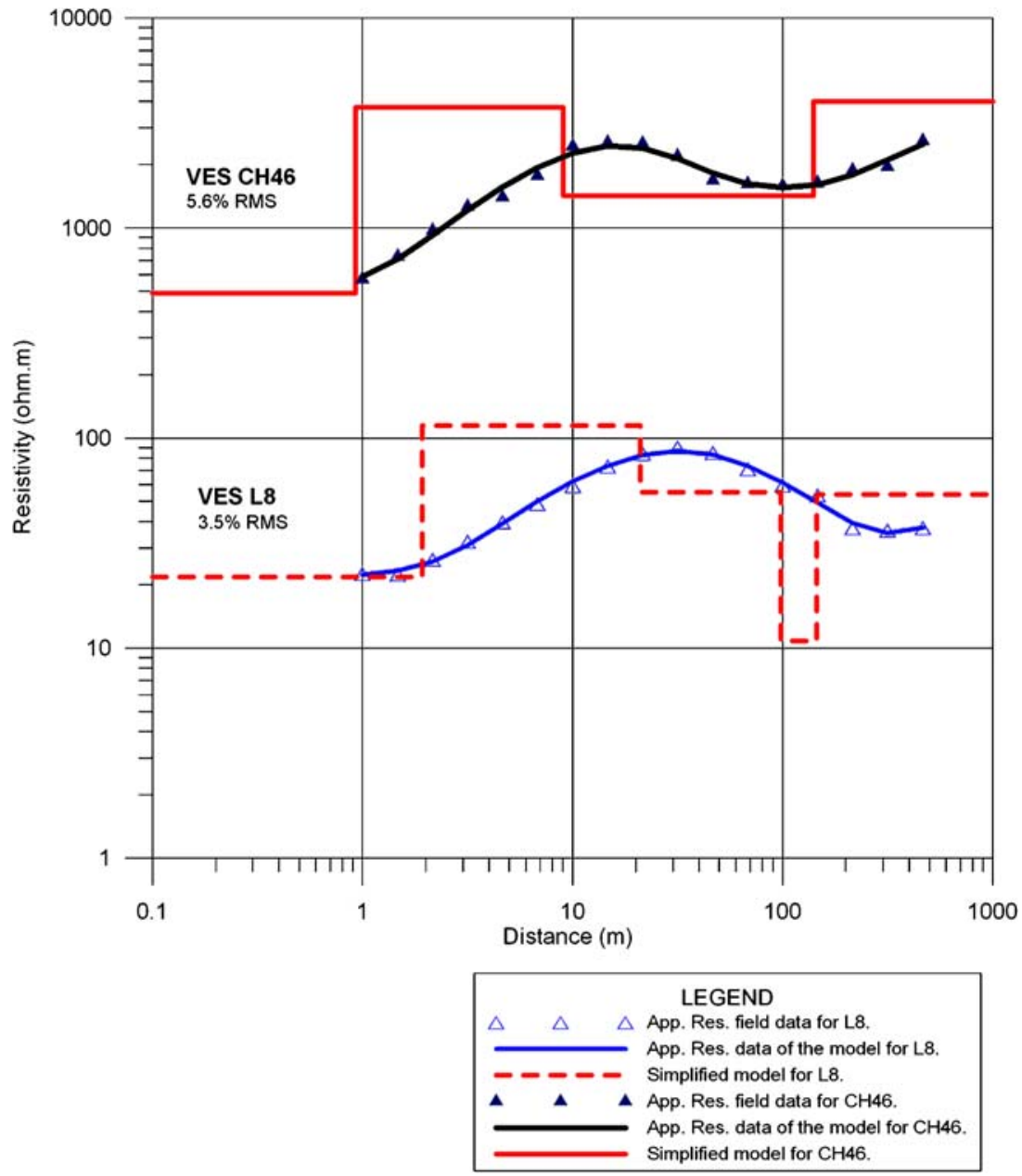
occurred between the aquifer and the Tamarindo Formation, and a second one between the Tamarindo Formation and the dense basement at depth, two zones of high density were delineated. The first one located along the volcanic chain and the second with a bearing SE-NW along the cities of León and Chinandega. Both structures are believed to be part of the depth dense basement. The zones of major sediment thickness are located within those structures.

\section{Electrical methods}

One of the most common geophysical methods for hydrogeological investigations is the direct current resistivity method. The resistivity method measures variations in the electrical resistivity of the ground by applying small electrical currents across arrays of electrodes inserted in the ground. During resistivity surveys, current is injected into the earth through a pair of current electrodes, and the potential difference is measured between one or several pair(s) of potential electrodes. The current and potential electrodes are generally arranged in a linear array.
Basically there are two major ways in which electrical charges can be transported through rocks, either by electronic conductivity or by electrolytic conductivity, where the latter is most important in common geologic materials.

The resistivity readings are processed to produce sections or volumes of the thickness and resistivity of subsurface electrical layers. Results are correlated with real ground interfaces such as soil and rock layering or soil-bedrock interfaces to provide information on subsurface structure.

\section{VES measurements}

A total of 51 VES were carried out in the LeónChinandega plains from July to August 1999 (Fig. 2). A Schlumberger array configuration was used for the soundings, with a maximum electrode spacing $(\mathrm{AB} / 2)$ ranging from 200 to $850 \mathrm{~m}$. All measurements were made with an ABEM SAS300C resistivity meter. The location of the VES was based on the available information from wells with geological information and in places where no information was available.

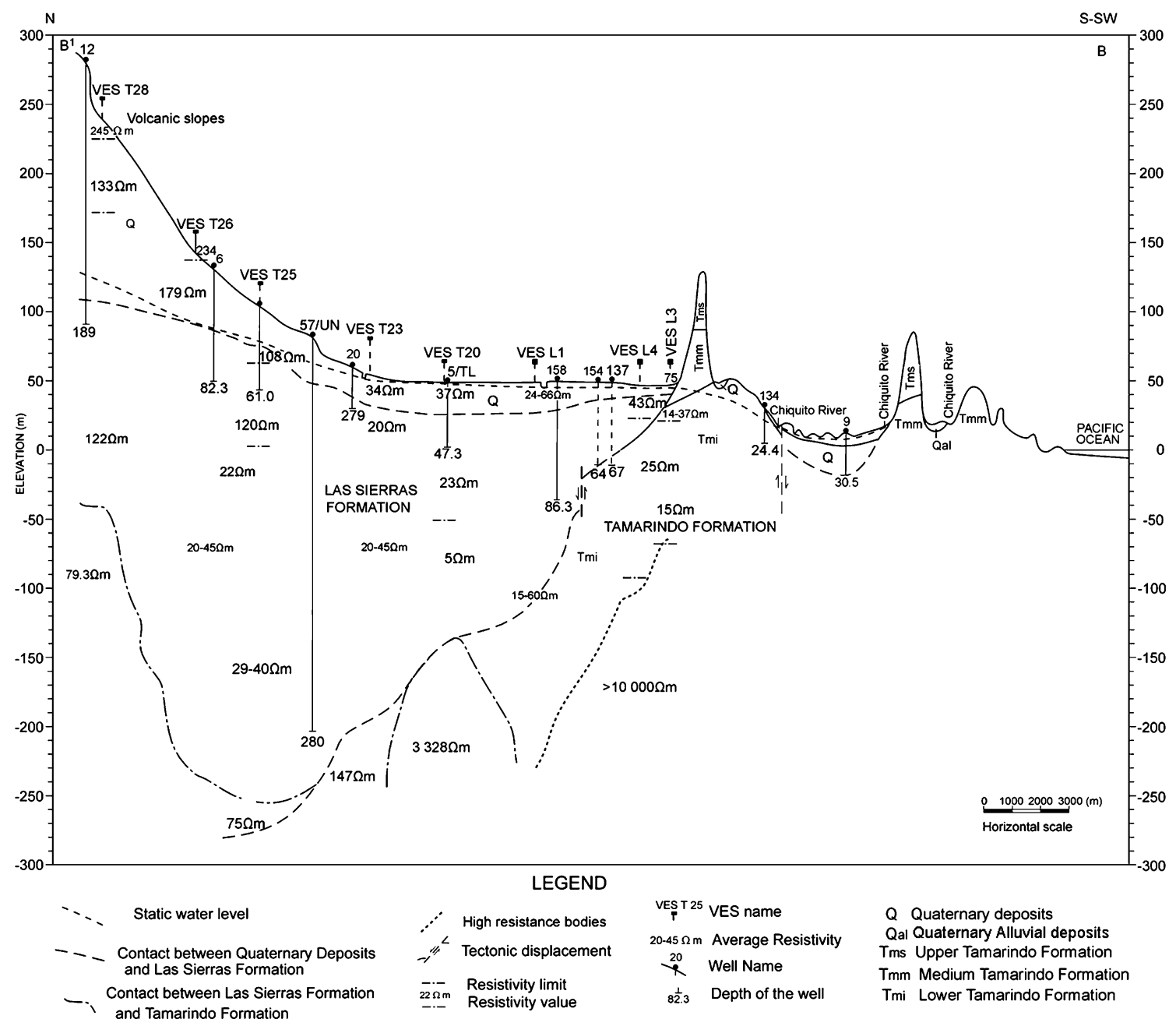

Fig. 4 Geoelectrical and geological interpreted cross section $B B^{\prime}$ in the León-Chinandega area 


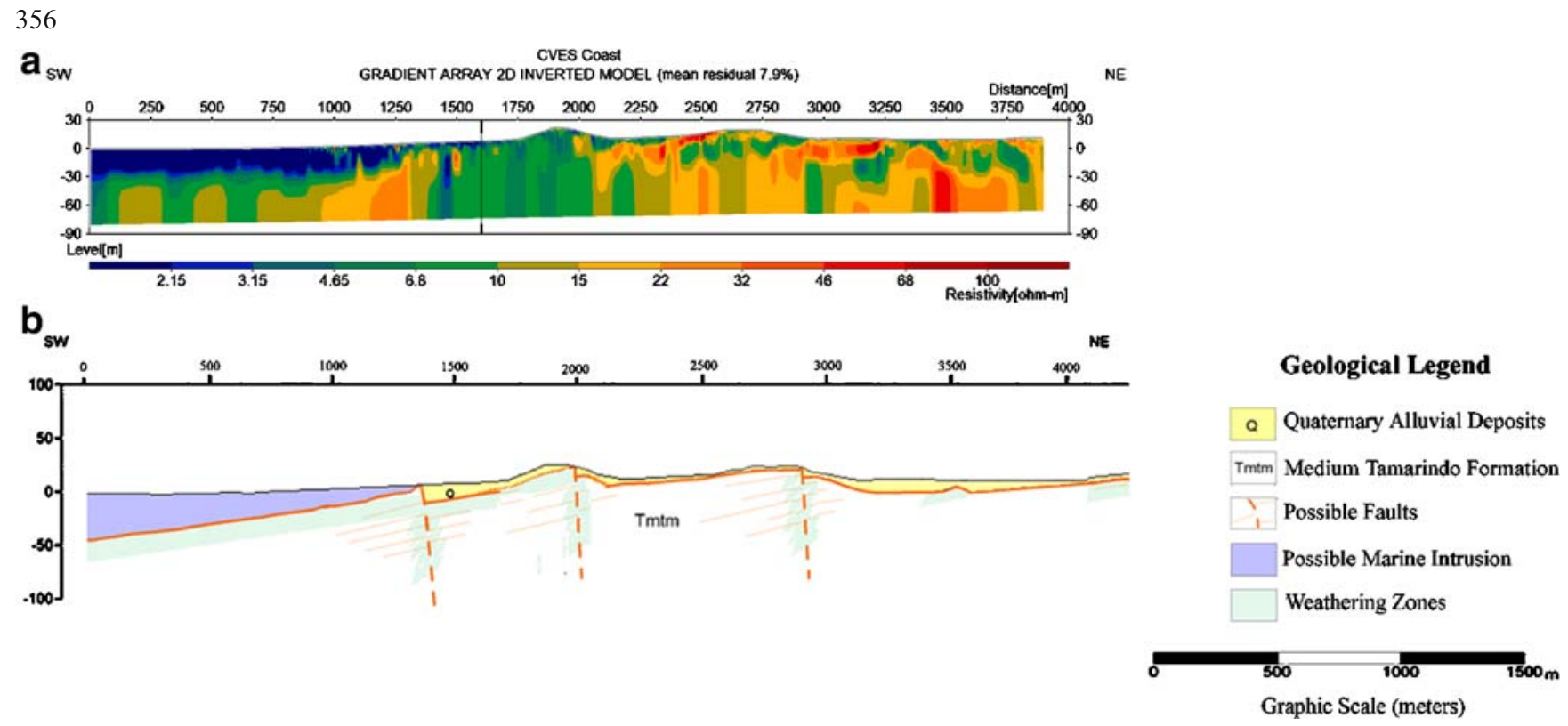

Fig. 5 Coastal environment. Inverted results from a profile near to the coast area (a) and its geological interpretation (b)

For each sounding, orthogonal (crossed) VES were carried out, and if the electrical measurements exhibited high variations, a new place was selected. The Schlumberger soundings were interpreted using the program Simultaneous Electromagnetic Layered Modeling and Analysis (SELMA), developed at Aarhus University (Christensen and Auken 1992), to estimate a well fitted one-dimensional model of resistivity. In some of the soundings, the maximum inverted model layer depth was about $450 \mathrm{~m}$. The interpreted geoelectrical layers were correlated with information from drilled wells in order to improve the characterization of the lithological resistivity values.

\section{CVES measurements}

The CVES resistivity data were collected using the ABEM Lund Imaging System with an array of 81 electrodes. The Lund Imaging system is a computercontrolled multi-electrode data acquisition system used for two-dimensional and three-dimensional high-resolution surveys, consisting of a resistivity meter, a relay switching unit, four multi-electrode cables and stainless steel electrodes; an external computer may be used in addition for a better overview of the data acquisition process. The multi-electrode cables have 21 takeouts with 5-m spacing. The last takeout of the cables was overlapped with the first

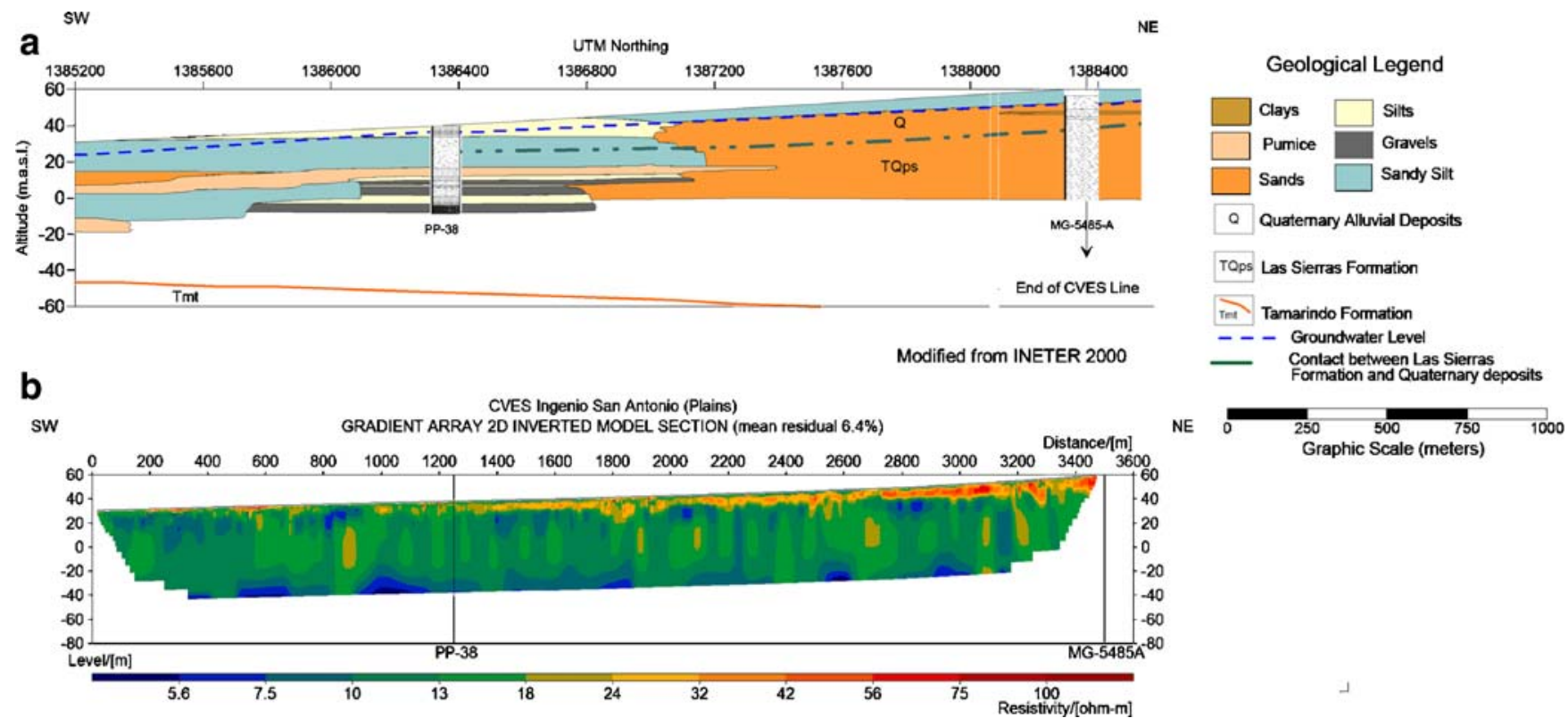

Fig. 6 Plains environment. The top figure (a) corresponds to a geological cross-section based only on the lithological information near the area of the CVES ISA plains. The bottom figure (b) presents the inverted results from the CVES ISA plains. The lithological descriptions of the wells are presented in Fig. 8 


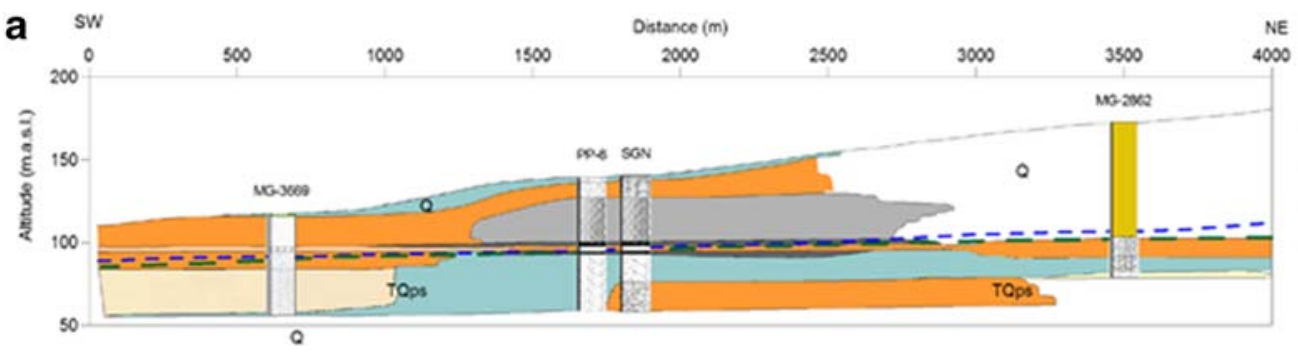

b

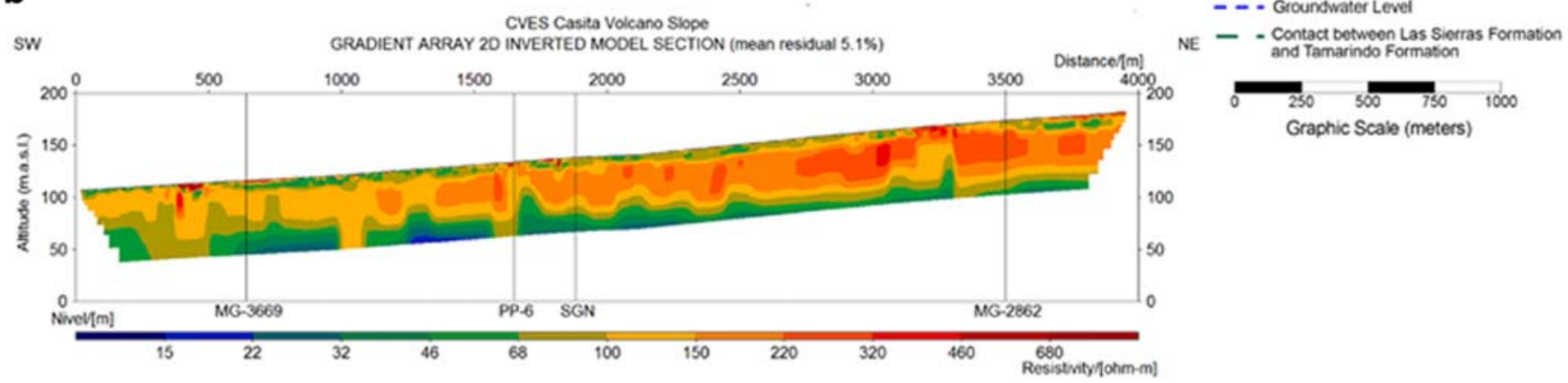

Fig. 7 Volcanic Slope Environment. The top figure (a) corresponds to a geological cross-section based on the lithological information near the area of the CVES Casita Volcano slope; the bottom figure (b) shows the inverted results from the CVES Casita Volcano slope. The lithological description of the wells are presented in Fig. 8

takeout of the next cable, giving a total of 81 actives electrodes. When deeper penetration was needed, the spacing between electrodes was increased to $10 \mathrm{~m}$ using four extension cables and four extra electrode cables. Extension of the survey can be achieved by a technique called "roll-along", in which a part of the original layout is shifted in the desired direction. Usually, this is a quarter of the total length of the total layout and new measurements are added to the survey (Dahlin 2001).

The interpretation of the data produced by the multielectrode systems was done by inverse numerical modeling techniques (inversion) based on finite difference or finite element methods (Oldenburg and Li 1994; Tsourlos 1995; Loke et al. 2003). The method tries to reduce the

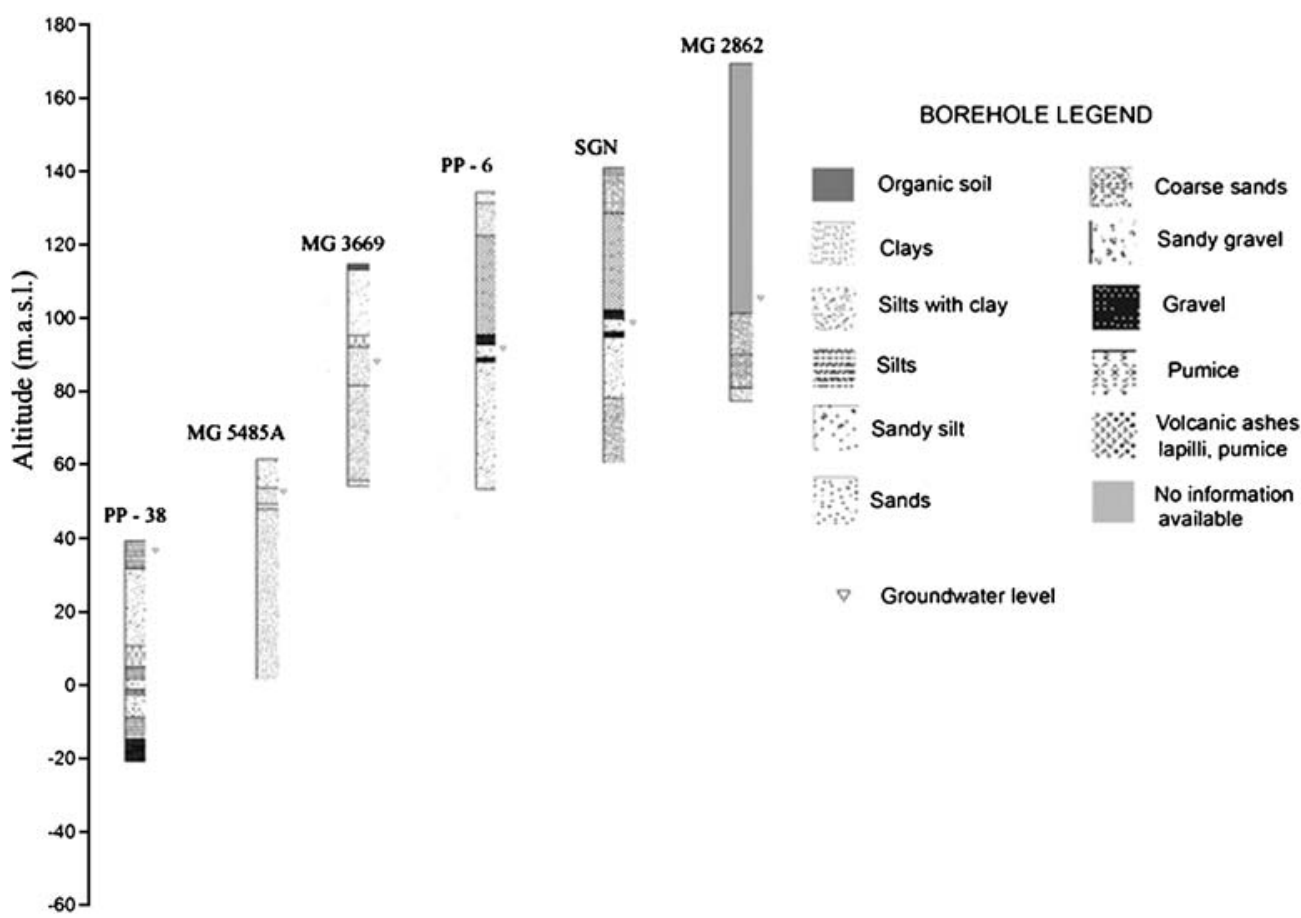

Fig. 8 Lithological information from the wells used for the geological cross-section in the plains and volcanic slope sub-areas. Wells PP38 and MG-5485-A correspond to the plains environment and wells MG-3669, PP-6, SGN and MG-2862 to the volcanic slope environment 
Table 1 Lithology and resistivity ranges from VES and CVES results

\begin{tabular}{ll}
\hline Lithological unit & Resistivity range in ohm.m \\
\hline $\begin{array}{l}\text { Coastal deposits (sands and gravels) and mangrove deposits (silty and } \\
\text { clayey sands) }\end{array}$ & $<5$ ohm.m (in areas of possible marine intrusion) \\
Sedimentary deposits (sands, silts and gravels) & $5-60 \mathrm{ohm} . \mathrm{m}$ (in coastal areas) \\
& $100-1,000 \mathrm{ohm} . \mathrm{m}$ (unsaturated) \\
Unconsolidated volcanic deposits & $20-100 \mathrm{ohm} . \mathrm{m}$ (saturated) \\
& $5-30 \mathrm{ohm} . \mathrm{m}$ (middle part of the plains, with substantial clay \\
Consolidated volcanic deposits (recent lava flows, lapilli and tuffs) & $1,000-4,000$ ohm.m (middle and upper part of the plains) \\
Weathered Tamarindo Formation & $5-10 \mathrm{ohm} . \mathrm{m}$ (clay layer product of the weathering of the \\
Tamarindo Formation (altered ignimbrites) & Tamarindo Formation) \\
Tamarindo Formation (tuffs, ignimbrites, andesites and basalts) & $60-100 \mathrm{ohm} . \mathrm{m}$ (in coastal areas) \\
\end{tabular}

differences between the resistivities measured and the calculated response of the estimated model carrying out a number of iteration steps, until satisfactory agreement between model response and field data is reached or no further improvement is possible (Dahlin 2001). The result is a two-dimensional earth profile built from mathematically modeled resistivities (Loke et al. 2003). In the inversion process, the subsurface is divided into a number of rectangular blocks with fixed dimensions, increasing the dimensions with depth. The RES2DINV resistivity inversion program (Loke 2004) was used to automatically invert the apparent resistivity data collected during the fieldwork campaigns.

A total of 50 CVES were carried out in the LeónChinandega plains from 1999 to 2005 (Fig. 2). Four different electrode configurations were used for this study; Wenner, Schlumberger, pole-dipole and multiple gradient.
An approximate length of $45 \mathrm{~km}$ was covered with a range of maximum depth penetration in the inverted models from 36 to $222 \mathrm{~m}$. The depth penetration of the survey depends primarily on the electrode separation and the electrode array configuration and secondarily on resistivity distribution in the earth.

\section{Results}

\section{Vertical electrical soundings}

The results of the geoelectrical survey show a complex structure towards the north due to different materials derived from the volcanic chain and a fracture pattern trending NE-SW (Fig. 1b). The VES carried out in the northern part, present a resistivity for the sediments and the volcanic material in the order of ten to several hundred

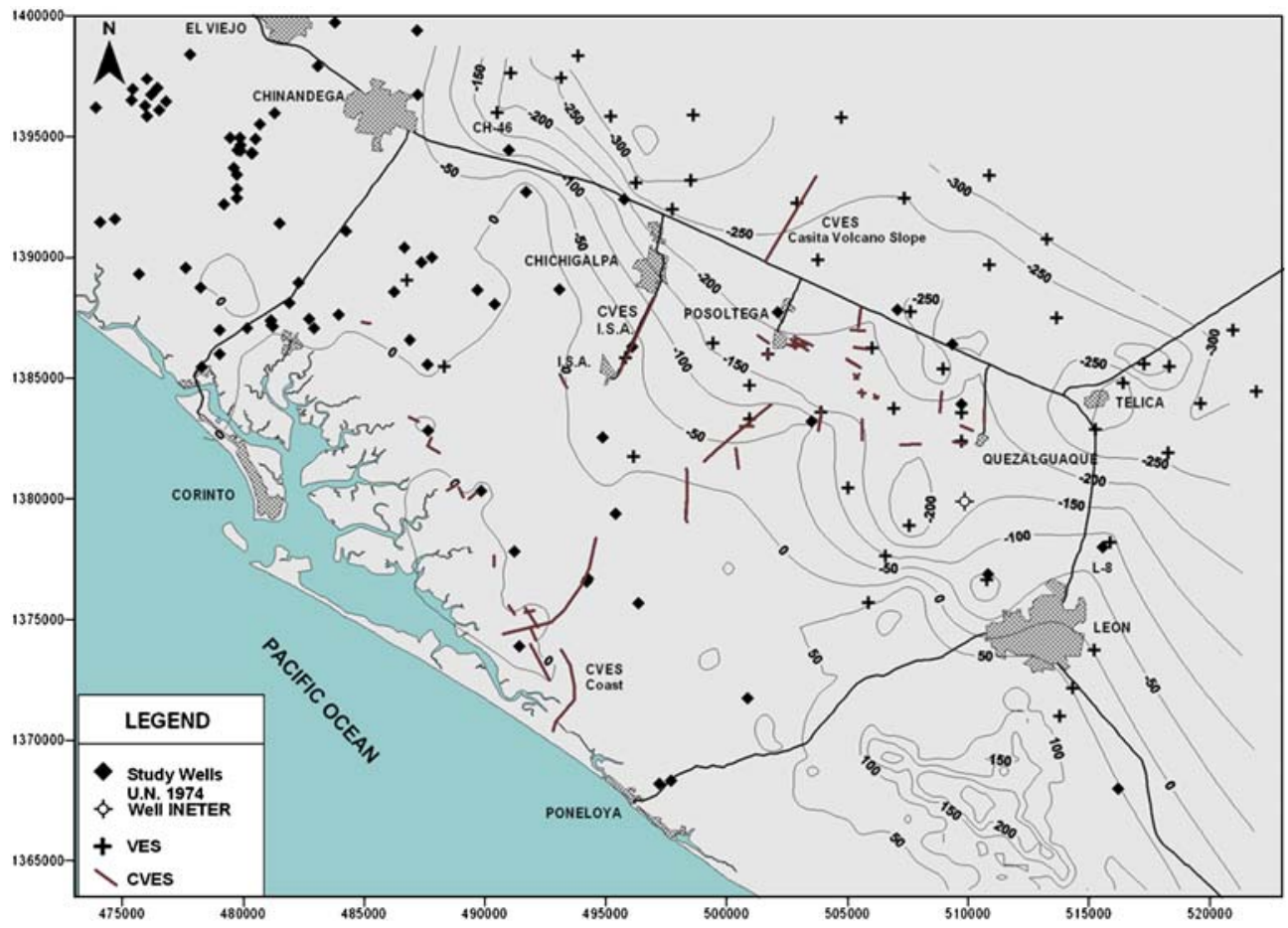

Fig. 9 Basement map of the León-Chinandega plains. The basement altitude contours are presented in meters above the sea level, at 50-m intervals. The wells with basement information (United Nations 1974) and VES are presented in the figure 


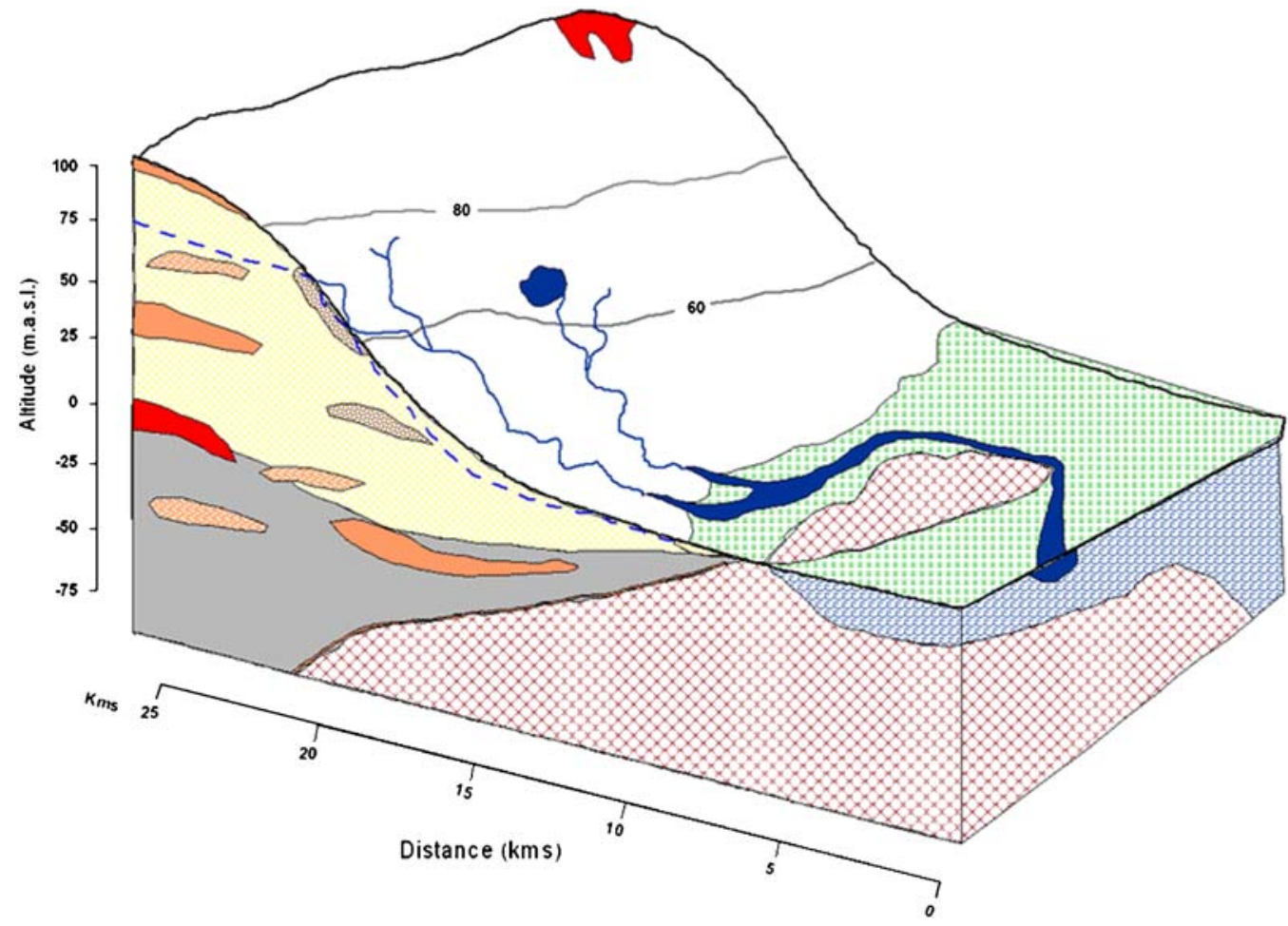

LEGEND

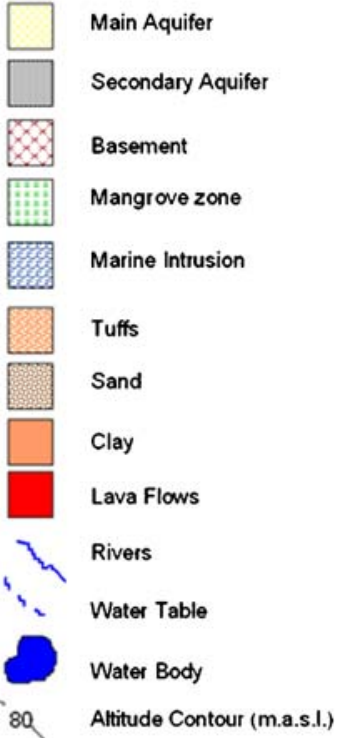

Fig. 10 Conceptual model for the hydrogeological situation in the León-Chinandega plains. In the mangrove areas near the coast, areas of marine intrusion are observed. In some parts the advance of the marine intrusion is stopped by the presence of outcrops of the basement

ohm meters, whereas the resistivity of the basement is in the order of $1,000 \mathrm{ohm} . \mathrm{m}$ or higher. Volcanic material which is strongly compacted at depth, with resistivities higher than 1,000 ohm.m, was interpreted as impermeable basement (Figs. 3 and 4 ).

The southern part of the area shows a very smooth stratification, with thick strata exhibiting resistivities varying between 15 and $60 \mathrm{ohm} . \mathrm{m}$, presumably associated with clays, silt, sand and volcanic scoria, decreasing in thickness towards the north. A high resistivity bottom layer is found at the northeast of the area, increasing in depth from the southwest to the northeast.

\section{Continuous vertical electrical soundings}

In this section, three CVES will be presented, each representative of the different geological sub-areas. All the profiles were inverted with a maximum of five iterations, and robust constrain (L1-norm) inversion was used for all the CVES. The smooth constrain least square inversion is more sensitive to the potential errors than the robust constrain inversion, but they present similar inverted models (Zhou and Dahlin 2003). Different vertical/horizontal flatness filter ratios $(\mathrm{V} / \mathrm{H}$ factors) were tested for the inversions, and although the inverted sections did not show big differences, a neutral $\mathrm{V} / \mathrm{H}$

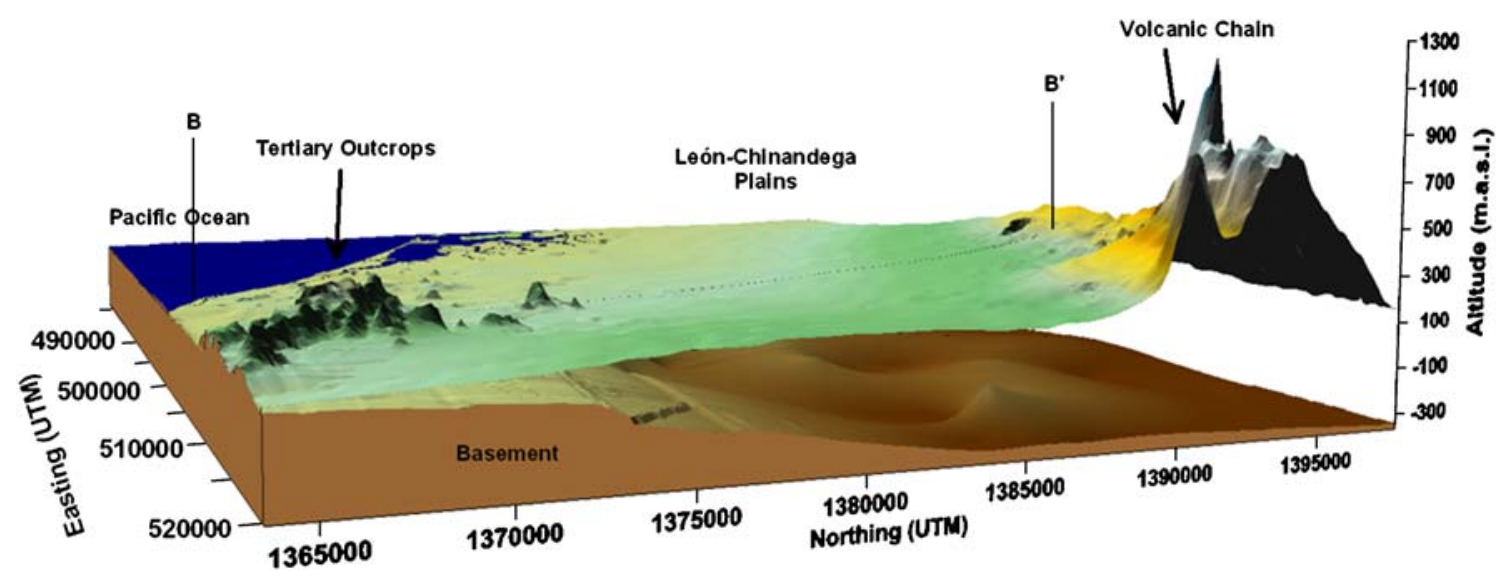

Fig. 11 Three-dimensional visualization of the basement and land surface of the León-Chinandega area. It is possible in the figure to observe how the basement is dipping towards the volcanic chain 
factor (1) was used for the inversions. No topographical corrections were carried out for the profiles with the exception of the coastal CVES, as the topography varies in a very slight way. The residuals values for the profiles presented here are in the range $4.4-7.8 \%$; these values are typical and considered normal if one takes in consideration the length of the arrays used.

The results of two-dimensional inverted resistivity profiles located close to the mangrove area, show very low resistivity values (less than $3 \mathrm{ohm} . \mathrm{m}$ ) which indicate the presence of saline water (Fig. 5). Higher resistivities in the lower parts of the inverted sections (more than $60 \mathrm{ohm} . \mathrm{m}$ ) are associated with volcanic rocks and interpreted as the basement; the rather low resistivity values associated with the basement in coastal areas are probably related to the presence of saline intrusion processes. However, zones of higher resistivity in the sediments above the basement may indicate groundwater outflow zones, and potential outflow zones can be identified in some inverted sections (not shown in this report).

The information obtained from the CVES Ingenio San Antonio in the middle part of the plains shows a regular geometry of layers with well-defined resistivity ranges. The resistivity results where correlated with lithologic information from well-driller logs, and summarized as an interpolated stratigraphy section in Fig. 6a. A total of five resistivity layers can be identify in this two-dimensional inverted model section. The thin top layer shows resistivity values between 10 and $18 \mathrm{ohm} . \mathrm{m}$ along the profile, except in the southwestern part of the profile where it is absent; this layer can be associated with unconsolidated volcanic deposits. Underlying this stratum, a higher resistivity layer is observed with resistivities up to $100 \mathrm{ohm} . \mathrm{m}$. The thickness of this layer ranges from less than $1 \mathrm{~m}$ up to $20 \mathrm{~m}$, and can be related to the nonsaturated pyroclastics deposits and alluvial deposits according to geological information from the wells in the area. A third low resistivity layer (around 5-10 ohm.m in the inverted section) is observed, associated with unconsolidated volcanic deposits with some clay content. This layer is thin in relation to the depth, and hence it is not possible to get a good estimate of thickness and resistivity due to equivalence. Below this layer, the resistivity increases and occasionally lenses of higher resistivity can be observed (up to $24 \mathrm{ohm} . \mathrm{m}$ ). The bottom layer presents lower resistivity, probably the clay layer that overlies the basement (Fig. 6b).

The volcanic slope sub-area presents a medium resistivity layer on top, associated with silty materials (Fig. 7). In places, a thin high-resistivity layer is visible on top of it. Below this layer, high resistivity values are found with values up to $400 \mathrm{ohm} . \mathrm{m}$, probably associated with recent Quaternary alluvial deposits. Underlying this layer, lower values are observed (15-100 ohm.m), probably related to sandy and clayey volcanic deposits. Two geological cross sections from the plains and volcanic slopes sub-areas are presented in Fig. 8. A general description of the electrical resistivity results and the associated lithologies are summarized in Table 1.
The geophysical information obtained from the VES and CVES was interpreted together with information from 82 wells that reach basement (United Nations 1974; CIGEO 1999; Corriols 2003). The data were extrapolated and a contour map of the basement was generated for the study area (Fig. 9).

After the VES field campaign, a first draft version of the map was made. A new deep well north of León city, drilled by INETER (Instituto Nacional de Estudios Territoriales) in 2000, agreed well with the preliminary version of the basement depth map, as the well reached a total depth of $210 \mathrm{~m}$ (125 masl) without intercepting the basement.

To the south of the city of León, the basement is observed as ridges oriented SE-NW. To the northwest of these hills, there are few outcrops of basement to be observed. The floor of the bedrock is not planar. It shows an irregular topography affected mainly by the fault system with NW-SE and NE-SW oriented faults and it is also affected by the volcanic chain. To the northeast of León city, the basement shows a strong depression around -150 masl. In the central part of the study area, the bedrock dips to the north towards the volcanic chain. In the areas below the cities of Posoltega and Quezalguaque, the results indicate that the basement is located at an altitude between -150 and -200 masl (Fig. 9).

\section{Conclusions}

The geophysical results indicate that the aquifer system in the León-Chinandega plains is mainly unconfined. Two well-defined aquifer units can be delimited (see Fig. 10). The first aquifer unit is found from a few meters depth down to $40-60 \mathrm{~m}$. It is possible to observe within this layer several lenses of higher resistivity associated with tuffs and coarser materials, and lenses with lower resistivity corresponding to deposits richer in clay. Below this unit, a secondary aquifer unit is observed with lower resistivity. The second unit is thicker than the first one and its thickness ranges between 60 to $100 \mathrm{~m}$ (Corriols 2003). Both aquifer units thin out towards the coast.

This geophysical investigation was carried out to improve the knowledge about the León-Chinandega aquifer geometry using the resistivity method. The region of the LeónChinandega plains offers favorable conditions for resistivity surveying since in most of the plains, the terrain has a flat topography; in addition, the lateral extent of the different geological units is normally large compared to their depths. Some exceptions are in areas where high-resistivity bodies such as lava flows can be found. Near the coast, towards the south, it is possible to observe areas of possible marine intrusion. To the north of the plains, the geology becomes more complex, as observed in the drilling records.

The VES are suitable for deep geophysical surveys, although they have limitations in areas with complex geology and topography. On the other hand, the CVES, with the lengths of electrode cable layouts available in this investigation, were not able to reach the Tertiary bedrock 
due to the thickness of the sediments. This limitation might be overcome with the use of longer electrode cable layouts that allow for an increase in the maximum depth of penetration. However, CVES are excellent for delimitating the geometry of the upper layers and their electrical responses, as well as for mapping the extension of the marine intrusion in coastal areas.

The geophysical models obtained of the plains generally indicate a regular three-layered system. In the plains area, the basement appears at levels around 40 to -250 masl, dipping towards the volcanic chain (see Fig. 11). According to geological logs and the resistivity data, the first layer with high resistivity values correspond to sands, silts and some clayey minerals. Underlying this layer, a thicker lower resistivity layer of volcanic deposits and tuffs, with a major presence of clayey minerals, is observed. Below this stratum, high resistivities are observed, probably related to consolidated volcanic materials such as lava flows and ignimbrites that work most likely as the impermeable basement of the aquifer.

In coastal areas, the geometry of the aquifer presents a different pattern; the impermeable basement can be found at shallow depths and in some cases cropping out at the surface. Those outcrops may form a natural barrier for the marine intrusion, but in some areas along the coast the absence of outcrops represents a risk for the aquifer (Fenzl 1983).

The geophysical results obtained by the United Nations study in 1974 were able to delimitate the resistivity contrast between the Tamarindo Formation and shallow sediments deposits near the coast, but they were not able to determine the thickness of the sedimentary filling towards the plain. The geophysical results from the United Nations report from 1974 also found a low-resistivity layer covering the basement in the soundings carried out. The results obtained from the CVES shows the presence of a thick low-resistivity unit. A recent electromagnetic study carried by Ryom (2004), within this research program, presents similar results regarding the depth of the first aquifer unit and its electrical response.

One of the major limitations for more detailed correlation between the stratigraphical units and the electrical models obtained is the lack of quality geological information from wells in the area. In order to improve the results, new lithological information is needed together with more detailed geophysical investigations, including geophysical logging. All the collected information represents a base for future hydrogeological works that will help in the planning, protection and decision-making regarding the groundwater management of the LeónChinandega plains.

Acknowledgements This investigation was performed with economic support from the Swedish International Development Authority (SIDA/SAREC), as part of a multi disciplinary cooperation program between Lund University and the Autonomous University of Nicaragua (UNAN-Managua). We also want to thank INETER (Nicaraguan Institute of Territorial Researches) for supporting part of the field-work investigation in this area.

\section{References}

Alvarez JA (1994) Níveis de Contaminacão das Águas da Bacia do Rio Atoya por Resíduos de Pesticidas Organoclorados e Organofosforados Aplicados na Cultura do Algodão: Bacia do Rio Atoya, Chinandega, Nicaragua, América Central [Levels of contamination in the waters of Rio Atoya Basin due to organochlorinated and organophosphorated pesticides residues applied by cotton cultivation: Rio Atoya Basin, Nicaragua, Central America]. Tese de Mestrado, Universidade Federal do Pará, Belem, Brazil, 132 pp

ARCAL XXXI (1999) Informe de Nicaragua: Estudio Isotopico y de la Contaminación del Acuifero León-Chinandega, Nicaragua [Nicaragua report: isotopic and contamination study of the León-Chinandega aquifer, Nicaragua]. Arreglos Regionales Cooperativos para la Promoción de la Ciencia y la Tecnologia Nucleares en America Latina y El Caribe, Lima, Peru, $52 \mathrm{pp}$

Cáceres V (2005) Caracterización de las Propiedades Resistivas de los Acuíferos Someros en la Zona Central de la Planicie de LeónChinandega [Characterization of the resistivity properties of shallow aquifers in the central part of the León-Chinandega Plain]. Tesis de grado, Facultad de Ciencias e Ingenierías, Universidad Nacional Autónoma de Nicaragua, Nicaragua, 108 pp

Calderón H (2003) Numerical modeling of the groundwater flow system in a sub-basin of the León-Chinandega Aquifer, Nicaragua. MSc Thesis, Department of Geology and Geophysics, University of Calgary, Canada, $206 \mathrm{pp}$

Christensen NB, Auken E (1992) Simultaneous electromagnetic layered model analysis. In: Jacobsen BH (ed) Proc. Interdisciplinary Inversion Workshop 1, Aarhus, Denmark, September 1992, GeoSkrifter 41, Aarhus University, Denmark, pp 49-56

CIGEO (1999) Estudio Geofísico de Resistividad Eléctrica entre las subcuencas de los ríos Chiquito y El Realejo, NW de Nicaragua, Volumen I [Geophysical survey by electrical resistivity methods within the sub-basin of Rio Chiquito and El Realejo, NW Nicaragua, vol 1]. Centro de Investigaciones Geocientíficas, CIGEO, UNAN-Managua, Managua, Nicaragua, $91 \mathrm{pp}$

Corriols M (2003) Hydrogeological, geophysical and hydrochemical investigations in the León-Chinandega Plains, Nicaragua. Licentiate Thesis LUTVDG/(TVTG-1013-SE, Lund University, Sweden, $156 \mathrm{pp}$

Dahlberg C, Odebjer W (2002) Investigation of hydrochemical characteristics and pesticide concentrations in groundwater at Posoltega, León-Chinandega Plains, Nicaragua: a minor field study. MSc Thesis, LUTVDG/TVTG-5077-SE. Lund University, Sweden, $157 \mathrm{pp}$

Dahlin T (2001) The development of DC resistivity imaging techniques. Comput Geosci 27:1019-1029

Delgado V (2003) Groundwater flow and water quality in a coastal plain aquifer in northwestern Nicaragua. MSc Thesis, University of Calgary, Canada, $177 \mathrm{pp}$

Elming S-Å, Layer P, Ubieta K (2001) A paleomagnetic study and age determinations of tertiary rocks in Nicaragua, Central America. Geophys J Int 147:294-309

Fenzl N (1983) Estudio de la Intrusión Marina en los Acuíferos Costeros de la Región León-Chinandega [Marine intrusion study in the coastal aquifers of the León-Chinadega Region]. Instituto Nacional de Estudios Territoriales, INETER, Managua, Nicaragua, $34 \mathrm{pp}$

IAEA (1971) Report on Environmental Isotope Studies. UNDP, International Atomic Energy Agency Special Fund Project NIC8, Nicaragua. IAEA, Vienna, Austria, $12 \mathrm{pp}$

INETER (2001) Estudios Hidrológicos e Hidrogeológicos en la Región del Pacífico de Nicaragua: Fase I, Región ChinandegaLeón-Nagarote, Informe Final [Hydrologic and hydrogeologic studies in the Pacific region of Nicaragua: phase 1, ChinandegaLeón-Nagarote Region]. Final Report, Instituto Nacional de Estudios Territoriales, INETER, Managua, Nicaragua, $52 \mathrm{pp}$

Kuang J (1971) Geología de la Costa del Pacífico de Nicaragua [Geology of the Pacific coast of Nicaragua]. Report No. 3, Geographical Survey of Nicaragua, Managua, Nicaragua 
Loke MH (2004) RES2DINV, Rapid 2-D resistivity \& IP inversion using the least-square method. Software manual, Geotomeo Software, Penang, Malaysia, $133 \mathrm{pp}$

Loke MH, Acworth I, Dahlin T (2003) A comparison of smooth and blocky inversion methods in 2-D electrical imaging surveys. Explor Geophys 34(3):182-187

Lopez A, Lacayo M, Cuadra J, Picado F (2000) Estudio de la Contaminación por Plaguicidas en el Acuífero y Suelos de la Región León-Chinandega, Nicaragua [Study of the pesticides pollution in the Aquifer and Soils of the León-Chinandega Region, Nicaragua]. Internal report, Centro para la Investigación en Recursos Acuáticos de Nicaragua, CIRA-UNAN, Managua, $20 \mathrm{pp}$

McBirney A, Williams NS (1965) Volcanic history of Nicaragua. University of California Press, Berkeley, CA, 63 pp

Oldenburg DW, Li Y (1994) Inversion of induced polarisation data. Geophysics 59:1327-1341

Payne BR, Yurtsever Y (1973) Environmental isotopes as a hydrogeological tool in Nicaragua. IAEA-SM-182/19, Department of Research and Isotopes, IAEA, Vienna, Austria, pp 195-202

Ryom M (2004) TemFast48 test and investigations in Nicaragua. MSc Thesis, University of Aarhus, Denmark, 143 pp
Tsourlos P (1995) Modeling interpretation and inversion of multielectrode resistivity survey data. $\mathrm{PhD}$ Thesis, University of York, UK, 315 pp

United Nations (1974) Investigaciones de Aguas Subterráneas en la Región del Pacífico de Nicaragua, Volumen I: Zona de Chinandega [Groundwater investigations in the Pacific region of Nicaragua, vol 1: Chinandega Zone]. UN, New York, 120 pp

Väisänen U, Kukkonen M, Rainio H, Pirkko L, Ulmos M, Balmaceda L, Guzman F, Larios R (2001) Problemas Ambientales en las Zonas de Tisma, León-Posoltega, Diriamba y Santo Tomas-La Libertad en Nicaragua [Environmental problems in the zones of Tisma, León-Posoltega, Diriamba and Santo Tomas-La Libertad, Nicaragua]. GTK and MTT, Finland, Universidad Nacional Agraria, UNA, Managua, Nicaragua

Wilson TC (1942) Geology of the Pacific coast area, Nicaragua. Summary report, Geological Survey of Nicaragua, Managua, Nicaragua

Zhou B, Dahlin T (2003) Properties and effects of measurement errors on two-dimensional resistivity imaging surveying. Near Surface Geophys 1(3):105-117

Zoppis-Bracci L, Del Guidicce D (1958) Geología de La Costa del Pacifico de Nicaragua [Geology of the Pacific Coast of Nicaragua]. Bol Servic Geol Nacional 2:24-68 